\title{
The Salvage Liver Transplantation in the Treatment of Hepatocelullar Carcinoma
}

\author{
Răzvan Tudor Grigorie, Gheorghe Moisă, Irinel Popescu
}

\author{
Corresponding author: \\ Gheorghe Moisă, MD, PhD student \\ Dan Setlacec Center of General \\ Surgery and Liver Transplantation, \\ Fundeni Clinical Institute, Bucharest \\ Romania \\ 258 Fundeni Street, 022328 \\ E-mail: gheorghe.moisa@yahoo.com
}

Received: 23.05.2017

Accepted: 08.06.2017

Copyright () Celsius Publishing House www.jtmr.ro
Dan Setlacec Center of General Surgery and Liver Transplantation, Fundeni Clinical Institute, Bucharest, Romania

\section{ABSTRACT}

Hepatocellular carcinoma (HCC) is the fifth most frequent cancer worldwide and in most cases it evolves on a cirrhotic liver, which requires a complex treatment strategy that includes different options. We present the case of a 62 years old patient, suffering from chronic HBV and HDV hepatitis, which was found, in 2011 with a $7 \mathrm{~cm} \mathrm{HCC} \mathrm{located} \mathrm{in} \mathrm{the}$ sixth segment of the liver and resected. Within less than a year, tumor relapse was detected (multiple nodules in the remaining sixth segment). Systemic chemotherapy (Sorafenib) started being administered and two TACE procedures were performed at one year and seven months difference. Despite that, the CT and MRI showed the evolution of the disease. The therapy was stopped and the patient was listed for liver transplantation and the procedure was performed. The thirteen months post transplantation assessment showed no sign of tumor relapse.

Abbreviations: HCC - hepatocellular carcinoma, HBV - hepatitis B virus, HDV - hepatitis D virus, TACE - transcatheter arterial chemoembolisation, MRI - magnetic resonance imaging, LT - liver transplantation, PEI - percutaneous ethanol injections, UCSF - University of California, San Francisco, MELD - Model for End-Stage Liver Disease, BCLC - Barcelona Clinic Liver Cancer, HKLC - Hong Kong Liver Cancer, SLT - salvage liver transplantation Key words: hepatocellular carcinoma, salvage, liver transplantation, resection

\section{INTRODUCTION}

Hepatocellular carcinoma (HCC) represents $80 \%$ (2) of the primary liver tumors, and is, overall, one of the most frequent cancers [(1) is the fifth (2) most frequent cancer in the world]. In most cases, it is associated with chronic liver diseases, especially with cirrhosis (in $80-90 \%(2,3)$ of cases HCC evolves on a cirrhotic liver, while 5-9\% (2) of the cirrhotic patients will develop a HCC). This association requires a complex treatment. The treatment options available today include surgical resection, liver transplantation (LT), local ablation (using hyper (microwaves, radiofrequency, laser, ultrasound or locally injected hot saline) or hypothermia or local percutaneous ethanol injections (PEI), transcatether arterial chemoembolization (TACE), chemotherapy and radiotherapy $(4,5)$. The only potentially curative options are the liver transplantation 
(especially for early stage tumor on advanced cirrhosis), which removes both the tumor and the chronic disease that led to it, but is limited by the scarcity of donors and resection (which is recommended whenever possible) (6).

Liver transplantation can be performed as the first procedure or after resection, if tumor relapse occurs (salvage liver transplantation) (2,7-28).

Downstaging and bridging are different strategies used in the HCC management $(4,29,30)$.

Downstaging is a strategy designed reduce the dimensions of tumors from outside of the criteria for resection or liver transplantation so they can meet the criteria and the procedure be performed. The downstaging procedures include percutaneous intratumoral pure alcohol injections, radiofrequency ablation, TACE or internal irradiation.

Bridging is designed to prevent dropout from the waiting list because of the tumor progression (31).

\section{CASE REPORT}

We report the case of a 62 years old male patient, who was found in 2004 with HBV and HDV hepatitis treated with Interferon between May 2005 and May 2006 (three doses each week), and then with Entecavir, starting from May $4^{\text {th }} 2009$ and which is still being administered at present.

In March 2011, as the follow-up revealed a $\alpha \mathrm{FP}$ value of $50 \mathrm{ng} / \mathrm{ml}$, a contrast-enhanced CT scan of the upper abdomen was performed, which showed a 7 centimeter tumor located in the $6^{\text {th }}$ segment of the liver

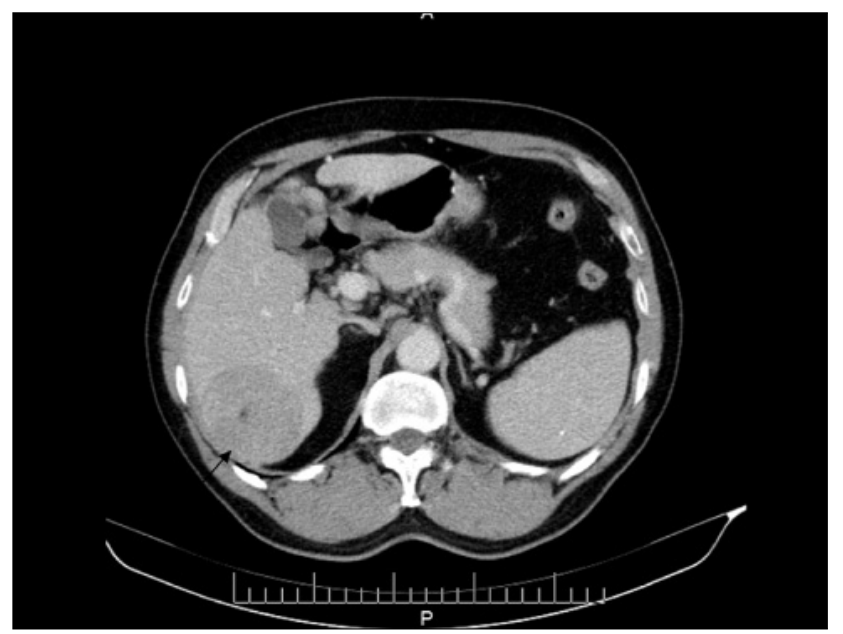

Figure 1 - Preoperative CT showing a $7 \mathrm{~cm}$ lesion located in the $6^{\text {th }}$ segment of the liver and an increased size of the left lobe; no ascites; the percutaneous tumor biopsy found moderately-poorly differentiated hepatocellular carcinoma grade II-III in Edmondson-Steiner system (figs. 1, 2).

The patient was admitted in our center on May $19^{\text {th }}$ 2011 for evaluation and therapeutic management.

Upon admission, physical examination revealed a patient with normal consciousness status and normal weight, normal pulmonary and cardiac auscultation, with a cardiac rate of 65 beats/minute and an arterial pressure on $130 / 80 \mathrm{mmHg}$. Abdominal examination showed absence of abdominal distension or ascites, but with a mild pain in the upper-right quadrant, and the inferior border of the liver aligned with the right costal margin.

Laboratory findings revealed a mild liver enzymes elevation and a $\alpha F P$ value of $79 \mathrm{ng} / \mathrm{ml}$.

The upper gastro-intestinal endoscopy and the total colonoscopy were normal.

Taking into account all these findings, the diagnosis was liver tumor (hepatocellular carcinoma) developed on chronic HBV and HDV infection and the therapeutic option was liver resection.

The tumor was surgically removed on May $25^{\text {th }} 2011$ (non-anatomic liver resection) when cirrhosis was also diagnosed (intraoperative finding).

The pathology examination of the specimen revealed a $6 \mathrm{~cm}$ hepatocellular carcinoma (moderatelypoorly differentiated hepatocellular carcinoma grade IIIII in Edmondson-Steiner system, thus confirming the biopsy). Non-tumoral liver parenchyma showed liver cirrhosis.

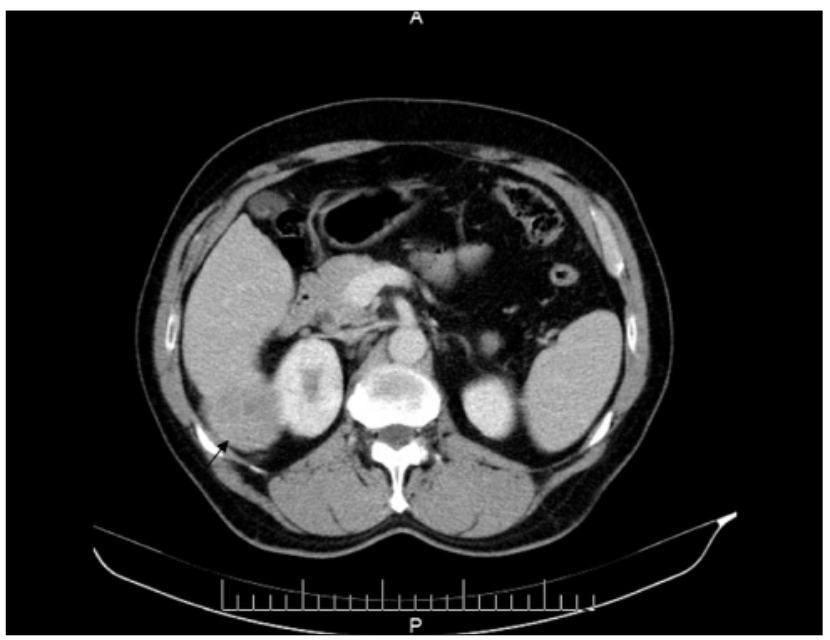

Figure 2 - The same CT scan, a more caudal CT slice 
The postoperative course was uneventful and the patient was discharged in the $12^{\text {th }}$ postoperative day in good clinical condition and having normal laboratory findings.

The follow-up consisted of CT scans each six months, ultra-sound scans between the CTs (three months after each (T) and blood tests each three months, until the next year, as seen further.

In 2012, multiple nodules, sized maximum $13 / 9 \mathrm{~mm}$ were found in the remaining $6^{\text {th }}$ segment. Transcatetheter arterial chemoembolisation was performed on March $27^{\text {th }} 2012$ and systemic chemotherapy (Sorafenib) started being administered in April $15^{\text {th }} 2012$ (four tablets daily) and since then, the blood tests were done each month.

In January $18^{\text {th }} 2013$ the CT scan reveals multiple pulmonary nodules, with the maximum diameters of 9 $\mathrm{mm}$. There was a suspicion of pulmonary metastases. A PET-CT scan was performed, but in could not determine if the nodules were metastases or not, since they were too small. However, the further follow-up showed no change in their number or dimensions (even in April 2016, as seen further), so this suspicion was abandoned.

The patient further assessment revealed a nodule in the 6th segment, which required a new TACE procedure (on October $14^{\text {th }} 2013$; the chemotherapy continuing being administered).

On January $15^{\text {th }} 2016$ the RM scan described multiple nodules scattered all over the liver parenchyma some of them suggesting tumoral processes (fig. 3).

The chemotherapy administration was stopped in December 1st 2015 and the patient was listed for liver

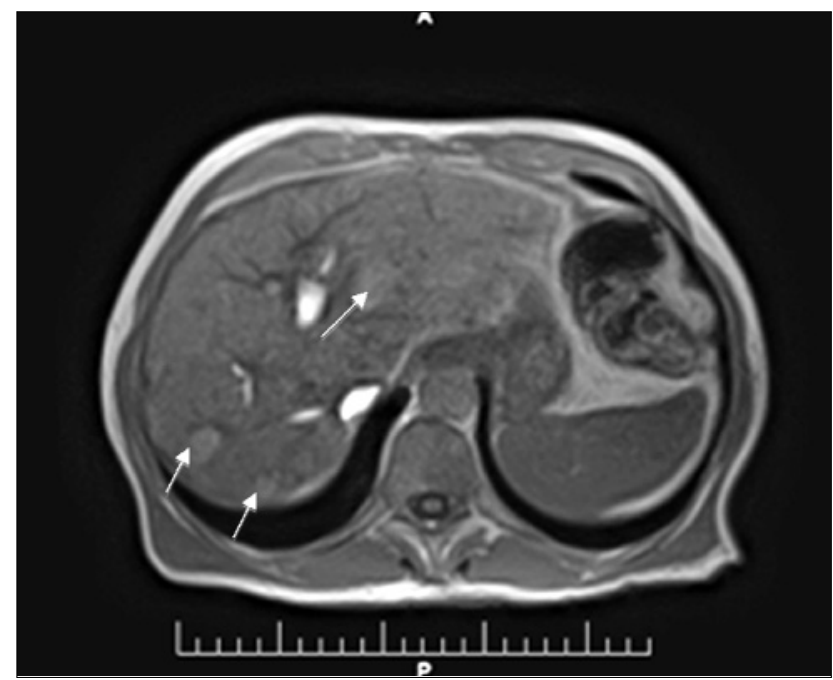

Figure 3 - MRI image three months before the transplantation showing multiple nodular lesions scattered all over the liver parenchyma transplantation (after completing the pre-transplant assessment (cardiologic and psychology evaluation, bacteriology (pharyngeal, nasal, blood, urine, feces) tests-negative- and whole body scintigraphy: no signs of bone metastases)).

The upper gastro-intestinal endoscopy described a sessile polyp measuring $5 \mathrm{~mm}, 34 \mathrm{~cm}$ from the dental arch and $2^{\text {nd }}$ degree esophageal varices; no other findings. The total colonoscopy showed internal hemorrhoids; no other findings.

On April 15th 2016, an isogrup liver graft from a brain-dead donor was available and the patient underwent an orthotopic liver transplantation.

The preoperative laboratory tests showed WBC 5090/mm $\mathrm{mm}^{3}$, HGB $11.1 \mathrm{~g} / \mathrm{dl}, 115000 \mathrm{PLT} / \mathrm{mm}^{3}$, ALT 229 U/L, AST 394 U/I , ALKP 217 U/I, үGT 221 U/I, TBil 2.2 $\mathrm{mg} / \mathrm{dl}$, urea $34.7 \mathrm{mg} / \mathrm{dl}$, creatinine $0.91 \mathrm{mg} / \mathrm{dl}$, glucose $87 \mathrm{mg} / \mathrm{dl}$, Na $139 \mathrm{mmol} / \mathrm{l}, \mathrm{K} 4.0 \mathrm{mmol} / \mathrm{l}$, INR 1.23 , $\alpha \mathrm{FP}$ $7.07 \mathrm{ng} / \mathrm{ml}$, CA $19-992.80 \mathrm{U} / \mathrm{ml}$ and CEA $6.7 \mathrm{ng} / \mathrm{ml}$.

The pathologic examination of the explanted liver showed a 4-centimeter tumor in the right lobe [a wellmoderately differentiated hepatocelullar carcinoma (Edmondson-Steiner II-III)] and, at quite a distance, a 2 $\mathrm{cm}$ nodule which showed high grade dysplasia.

The non-tumoral liver parenchyma presented liver cirrhosis. The lymph nodes did not present metastases (pNO).

The postoperative staging revealed a stage I hepatocelullar carcinoma (pT1pNOpMx).

For induction of the immunosuppression, Basiliximab and Methylprednisolone were used, delivered intraoperatively. The patient received the second dose of Basiliximab in the 3rd postoperative day. For the immunosuppression maintenance Tacrolimus and Mycophenolate mofetil were administered.

A total bilirubin level elevation to $5.6 \mathrm{mg} / \mathrm{dl}$ called for administration of Dexamethasone, which corrected the bilirubin level. Following that, a elevation of the blood liver enzymes was detected and it was solved with Methylprednisolone and Acetylcysteine.

A minimal operative wound suppuration was found. The bacteriology test revealed MRSA, which was solved with Linezolid and Fluconazole and daily would lavages.

No other postoperative course events happened and the patient was discharged in the 21st postoperative day, in good clinical condition and having the following liver tests: WBC $7560 / \mathrm{mm}^{3}$, HGB $10.10 \mathrm{~g} / \mathrm{dl}, 424000$ PLT $/ \mathrm{mm}^{3}$, ALT $58 \mathrm{U} / \mathrm{L}$, AST $57 \mathrm{U} / \mathrm{l}$, VGT $163 \mathrm{U} / \mathrm{l}$, TBil 0.5 $\mathrm{mg} / \mathrm{dl}$, urea $54.80 \mathrm{mg} / \mathrm{dl}$, creatinine $1.24 \mathrm{mg} / \mathrm{dl}$, glucose $84.70 \mathrm{mg} / \mathrm{dl}$, Na $143 \mathrm{mmol} / \mathrm{l}, \mathrm{K} 5.0 \mathrm{mmol} / \mathrm{l}$.

The Mycophenolate mofetil was stopped three months after transplantation and the pacient continued 
to receive Tacrolimus for the rest of his life.

To avoid HBV recurrence, the patient receives Hepatitis B Immunoglobulin (2000 UI when the plasma level of $H B s$ Ab is less than $200 \mathrm{U} / \mathrm{I})$.

The last viral assessment on October 2016 showed no sign of HVB in the patient's blood.

The post transplantation follow-up consisted of blood samples each two weeks, ultrasound scans each month and CT scans at 3, 6 and 12 months after the transplantation.

At present (13 months after liver transplantation), the patient is disease-free, without evidence of recurrence on CT scan (on May $9^{\text {th }}$ 2017), and normal laboratory tests: WBC $6800 / \mathrm{mm}^{3}$, HGB $13.9 \mathrm{~g} / \mathrm{dl}, 196000 \mathrm{PLT} / \mathrm{mm}^{3}$, AST $24 \mathrm{U} / \mathrm{l}$, ALKP $140 \mathrm{U} / \mathrm{I}$, , $\mathrm{GT} 139 \mathrm{U} / \mathrm{I}$, TBil $0.6 \mathrm{mg} / \mathrm{dl}$, urea 43 $\mathrm{mg} / \mathrm{dl}$, creatinine $0.81 \mathrm{mg} / \mathrm{dl}$, glucose $81 \mathrm{mg} / \mathrm{dl}$, Na 142 $\mathrm{mmol} / \mathrm{l}, \mathrm{K} 4.3 \mathrm{mmol} / \mathrm{l}, \alpha \mathrm{FP} 3.3 \mathrm{ng} / \mathrm{ml}$, CA $19-95.84 \mathrm{U} / \mathrm{ml}$ and CEA $1.47 \mathrm{ng} / \mathrm{ml}$, CMV IgM 0.18, tacrolinemia 4.6 $\mathrm{ng} / \mathrm{ml}$.

\section{DISCUSSIONS}

The association hepatocellular carcinoma-cirrhosis requires a complex treatment management and different protocols were designed in order to assess the tumor, the stage of the cirrhosis and to decide the best strategy (which remains a subject of debate). There are several therapeutic options of which liver transplantation and the resection are the only potentially curative ones. The liver transplantation has the advantage of removing the tumor and the diseased liver (which is a potential source of new tumors), but is impaired by the scarcity of donors, and the difficulties and risks that immunosuppression brings with it, while the resection allows the patient to continue living with his native liver (with no need for immunosuppression), but has a greater rate of tumor recurrence.

One of the most well known systems used to stage the tumor [and to decide whether or not a liver transplantation can be done for hepatocellular carcinoma on liver cirrhosis with good results (in terms of survival after 5 years or disease-free survival)] is the Milan system (single tumor $\leq 5 \mathrm{~cm}$ or no more than three tumors none $>3 \mathrm{~cm}$, with no vascular invasion and no extra-hepatic extension of the disease)(32). Since patients with tumors outside the Milan criteria still had good results after undergoing liver transplantation, these criteria were extended. Hence, systems like UCSF (University of California, San Francisco) (single tumor $<6.5 \mathrm{~cm}$ or no more than 3 tumors, none bigger than $4.5 \mathrm{~cm}$, and cumulative tumor size $<8 \mathrm{~cm}$, with no vascular invasion and no extra-hepatic extension)(32) or up-to-seven (or the new Milan criteria: seven as the sum of the largest tumor (in $\mathrm{cm}$ ) and the number of tumors) (33) have been developed $(29,34)$. And even for tumors outside these criteria down-staging procedures can be used in order to bring tumors inside them. The down-staging protocol inclusion criteria are: 1) one tumor $\leq 8 \mathrm{~cm}, 2$ ) 2-3 tumors $\leq 5 \mathrm{~cm}$ each and with cumulative tumor size $<8 \mathrm{~cm}, 3) 4$ 5 tumors, none bigger than $3 \mathrm{~cm}$, and with cumulative tumor size less than $8 \mathrm{~cm}$ (2). These systems can be also used to decide whether or not the resection is a good option (30).

In order to asses the liver function impairment due to cirrhosis are the Child-Pugh-Turcotte and the Model for End-Stage Liver Disease (MELD) scores.

As far as the treatment strategy is concerned, different systems have also been developed, like BCLC (Barcelona Clinic Liver Cancer)-the only system endorsed by the European Association for the Study of the Liver and the American Association for the Study of Liver Disease (35), HKLC (Hong Kong Liver Cancer) and many others which try to indicate the therapy strategy for each combination of disease (cancer and cirrhosis) stage (35). The recent consensus meetings (based on a great body of evidence from studies in Western and Asian countries) stated that HCC involving a single tumor, regardless of its size should be resected, whenever technically possible (35) and, of course, when the volume and function of the remaining liver allows that.

The resection was the first step in our reported case's therapy. Within less than one year, relapse was found and systemic therapy was initiated and two TACE procedures were performed (at more than a year distance). But the disease continued to evolve despite this therapy, therefore the patient was listed for a liver transplantation, which was performed on the $15^{\text {th }}$ of April 2016. The thirteen months post transplantation assessment shows no sign of relapse.

The liver transplant in this case was a salvage liver transplantation (SLT) for relapses within Milan criteria after the resection, which couldn't be controlled by systemic chemotherapy and TACE $(28,36-52)$.

\section{CONCLUSIONS}

Hepatocellular carcinoma is the fifth most frequent cancer in the world and in most cases it evolves on a cirrhotic liver. This association requires a complex algorithm for finding the best therapy for the given stage of the tumor and the given stage of the liver disease (plus the patient performance status and other diseases he may have), and there are still debates about which the best option might be. 
For the reported case, the patient's evolution so far suggests that the transplantation was an inspired choice for this case.

The systemic therapy and TACE may be seen as bridging therapies.

\section{REFERENCES}

1. Vivarelli M, Montalti R, Risaliti A. Multimodal treatment of hepatocellular carcinoma on cirrhosis: An update. World J Gastroenterol. 2013;19(42):7316-26. doi: 10.3748/wjg.v19.i42.7316.

2. Popescu I, Sirbu-Boeti MP. Carcinomul hepatocelular. În Popescu I, editor. Chirurgie generala. Tratat de chirurgie. Bucuresti: Editura Academiei Române; 2009. p. 553-65.

3. Jain D. Liver and intrahepatic bile ducts - tumor. Hepatocellular carcinoma - General. Retrieved from www.pathologyoutlines.com

4. Eguchi S, Hidaka M, Tomonaga T, Miyazaki K, Inokuma T, Takatsuki M, et al. Actual therapeutic efficacy of pre-transplant treatment on hepatocellular carcinoma and its impact on survival after salvage living donor liver transplantation. J Gastroenterol. 2009:44(6):624-9. doi: 10.1007/s00535-009-0043-9. Epub 2009 Apr 21.

5. Perini MV, Starkey G, Fink MA, Bhandari R, Muralidharan V, Jones R, et al. From minimal to maximal surgery in the treatment of hepatocarcinoma: A review. World J Hepatol. 2015 Jan 27;7(1):93-100. doi: 10.4254/wjh.v7.i1.93.

6. Earl TM, Chapman WC. Hepatocellular carcinoma: resection versus transplantation. Semin Liver Dis. 2013 Aug;33(3):282-92. doi: 10.1055/s-0033-1351783. Epub 2013 Aug 13.

7. Cucchetti A, Vitale A, Del Gaudio M, Ravaioli M, Ercolani G, Cescon M, et al. Harm and benefits of primary liver resection and salvage transplantation for hepatocellular carcinoma. Am J Transplant. 2010 Mar;10(3):619-27. doi: 10.1111/j.1600-6143.2009.02984.x. Epub 2010 Jan 29.

8. Sala M, Fuster J, Llovet JM, Navasa M, Solé M, Varela M, et al. High pathological risk of recurrence after surgical resection for hepatocellular carcinoma: an indication for salvage liver transplantation. Liver Transpl. 2004 0ct;10(10):1294-300.

9. Laurent A, Tayar C, Andréoletti M, Lauzet JY, Merle JC, Cherqui D. Laparoscopic liver resection facilitates salvage liver transplantation for hepatocellular carcinoma. J Hepatobiliary Pancreat Surg. 2009;16(3): 310-4. doi: 10.1007/s00534-009-0063-0. Epub 2009 Mar 12.

10. Cherqui D, Laurent A, Mocellin N, Tayar C, Luciani A, Van Nhieu JT, et al. Liver resection for transplantable hepatocellular carcinoma: longterm survival and role of secondary liver transplantation. Ann Surg. 2009 Nov;250(5):738-46. doi: 10.1097/SLA.0b013e3181bd582b.

11. Moon JI, Kwon CH, Joh JW, Choi GS, Jung GO, Kim JM, et al. Primary versus salvage living donor liver transplantation for patients with hepatocellular carcinoma: impact of microvascular invasion on survival. Transplant Proc. 2012 Mar;44(2):487-93. doi: 10.1016/ j.transproceed.2011.11.009.

12. Wang P, Pu Y, Li H, Shi B, Zheng S, Zhong L. Prognosis for recipients with hepatocellular carcinoma of salvage liver transplantation versus those of primary liver transplantation: a retrospective single-center study. Springerplus. 2016 Oct 18;5(1):1809. eCollection 2016.

13. Hu Z, Wang W, Li Z, Ye S, Zheng SS. Recipient outcomes of salvage liver transplantation versus primary liver transplantation: a systematic review and meta-analysis. Liver Transpl. 2012 Nov;18(11):1316-23. doi: 10.1002/lt.23521.

14. Felli E, Cillo U, Pinna AD, De Carlis L, Ercolani G, Santoro R, et al. Salvage liver transplantation after laparoscopic resection for hepatocellular carcinoma: a multicenter experience. Updates Surg. 2015 Jun;67(2):215-22. doi: 10.1007/s13304-015-0323-2. Epub 2015 Jul 25.

15. Qu W, Zhu ZJ, Sun LY, Wei L, Liu Y, Zeng ZG. Salvage liver transplantation for hepatocellular carcinoma recurrence after primary liver resection. Clin Res Hepatol Gastroenterol. 2015 Feb;39(1):93-7. doi: 10.1016/j.clinre.2014.07.006. Epub 2014 Aug 21.

16. Wu L, Hu A, Tam N, Zhang J, Lin M, Guo Z, He X. (2012)
Salvage liver transplantation for patients with recurrent hepatocellular carcinoma after curative resection. PLOS ONE. Retrieved from http://www.plosone.org/article/fetchObjectAttachment.action?uri=info \%3Adoi\%2F10.1371\%2Fjournal.pone.0041820\& representation=PDF $\% 5$ Cnhttp://ovidsp.ovid.com/ovidweb.cgi?T=JS\&PAGE=reference\&D= emed10\&NEWS=N\&AN=2012470923

17. Kim BW, Park YK, Kim YB, Wang HJ, Kim MW. Salvage liver transplantation for recurrent hepatocellular carcinoma after liver resection: feasibility of the Milan criteria and operative risk. Transplant Proc. 2008 Dec;40(10):3558-61. doi: 10.1016/j.transproceed.2008.03.175.

18. Hu Z, Zhou J, Li Z, Xiang J, Qian Z, Wu J, et al. Salvage liver transplantation for recurrent hepatocellular carcinoma after liver resection: retrospective study of the Milan and Hangzhou criteria. PLOS One. 2014 Jan 27;9(1):e87222. doi: 10.1371/journal.pone.0087222. eCollection 2014.

19. Liu F, Wei Y, Wang W, Chen K, Yan L, Wen T, et al. Salvage liver transplantation for recurrent hepatocellular carcinoma within UCSF criteria after liver resection. PLoS One. 2012;7(11):e48932. doi: 10.1371/ journal.pone.0048932. Epub 2012 Nov 8 .

20. Li HY, Wei YG, Yan LN, Li B. Salvage liver transplantation in the treatment of hepatocellular carcinoma: a meta-analysis. World $\mathrm{J}$ Gastroenterol. 2012 May 21;18(19):2415-22. doi: 10.3748/ wjg.v18.i19.2415.

21. Zhu Y, Dong J, Wang WL, Li MX, Lu Y. Short- and long-term outcomes after salvage liver transplantation versus primary liver transplantation for hepatocellular carcinoma: a meta-analysis. Transplant Proc. 2013 Nov;45(9):3329-42. doi: 10.1016/j.transproceed.2013.06.004.

22. Yamashita $\mathrm{Y}$, Yoshida $\mathrm{Y}$, Kurihara T, Itoh S, Harimoto N, Ikegami T, et al. Surgical results for recurrent hepatocellular carcinoma after curative hepatectomy: Repeat hepatectomy versus salvage living donor liver transplantation. Liver Transpl. 2015 Jul;21(7):961-8. doi: 10.1002/t.24111. Epub 2015 May 4.

23. Chan DL, Alzahrani NA, Morris DL, Chua TC.Systematic review of efficacy and outcomes of salvage liver transplantation after primary hepatic resection for hepatocellular carcinoma. J Gastroenterol Hepatol. 2014 Jan;29(1):31-41. doi: 10.1111/jgh.12399.

24. Cucchetti A, Cescon M, Trevisani F, Morelli MC, Ercolani G, Pellegrini $\mathrm{S}$, et al. What is the probability of being too old for salvage transplantation after hepatocellular carcinoma resection? Dig Liver Dis. 2012 Jun;44(6):523-9. doi: 10.1016/j.dld.2012.01.018. Epub 2012 Mar 3.

25. Tribillon E, Barbier L, Goumard C, Irtan S, Perdigao-Cotta F, Durand F, et al. When Should We Propose Liver Transplant After Resection of Hepatocellular Carcinoma? A Comparison of Salvage and De Principe Strategies. J Gastrointest Surg. 2016 Jan;20(1):66-76; discussion 76. doi: 10.1007/s11605-015-3018-6. Epub 2015 Nov 18.

26. Landman MP, Feurer ID, Pinson CW, Moore DE. Which is more cost-effective under the MELD system: Primary liver transplantation, or salvage transplantation after hepatic resection or after locoregional therapy for hepatocellular carcinoma within Milan criteria? HPB (Oxford). 2011 Nov;13(11):783-91. doi: 10.1111/j.14772574.2011.00355.x. Epub 2011 Aug 19.

27. Shan Y, Huang L, Xia Q. Salvage Liver Transplantation Leads to Poorer Outcome in Hepatocellular Carcinoma Compared with Primary Liver Transplantation. Sci Rep. 2017 Mar 15;7:44652.

28. Liang BY, Huang ZY, Zhou SJ, Hou P, Wang SF, Jiang B, et al. Primary results of salvage liver transplantation in the patients with unresectable recurrent hepatocellular carcinoma after initial liver resection. Hepatogastroenterology. 2014 0ct;61(135):2014-20.

29. Kornberg A. Liver transplantation for hepatocellular carcinoma beyond Milan criteria: multidisciplinary approach to improve outcomee. ISRN Hepatol. 2014 Mar 4;2014:706945. doi: 10.1155/2014/706945. eCollection 2014.

30. Facciuto ME, Koneru B, Rocca JP, Wolf DC, Kim-Schluger L, Visintainer $P$, et al. Surgical treatment of hepatocellular carcinoma beyond Milan criteria. Results of liver resection, salvage transplantation, and primary liver transplantation. Ann Surg Oncol. 2008 May;15(5):1383-91. doi: 10.1245/s10434-008-9851-z. Epub 2008 Mar 5.

31. Prasad MA, Kulik LM. The role of bridge therapy prior to orthotopic liver transplantation. J Natl Compr Canc Netw. 2014 Aug;12(8):118390; quiz 1191.

32. Duffy JP, Vardanian A, Benjamin E, Watson M, Farmer DG, Ghobrial 
RM, et al. Liver transplantation criteria for hepatocellular carcinoma should be expanded: a 22-year experience with 467 patients at UCLA. Ann Surg. 2007 Sep;246(3):502-9; discussion 509-11.

33. Lei JY, Wang WT, Yan LN. Up-to-seven criteria for hepatocellular carcinoma liver transplantation: a single center analysis. World $\mathrm{J}$ Gastroenterol. 2013 Sep 28;19(36):6077-83.

34. Zhang HM, Jiang WT, Pan C, Deng YL, Zheng H, Shen ZY. Milan criteria, University of California, San Francisco, criteria, and model for end-stage liver disease score as predictors of salvage liver transplantation. Transplant Proc. 2015 Mar;47(2):438-44.

35. Zhong J, Torzilli G, Xing H, Han J, Liang L, Zhang H, et al. Controversies and evidence of hepatic resection for hepatocellular carcinoma. BBA Clinical. 2016; 6:125-130. http://doi.org/http:// dx.doi.org/10.1016/ j.bbacli.2016.10.001

36. Abe T, Tashiro H, Teraoka Y, Hattori M, Tanimine N, Kuroda S, et al. Efficacy and Feasibility of Salvage Living Donor Liver Transplantation after Initial Liver Resection in Patients with Hepatocellular Carcinoma. Dig Surg. 2016;33(1):8-14

37. Hu RH1, Ho MC, Wu YM, Yu SC, Lee PH. Feasibility of salvage liver transplantation for patients with recurrent hepatocellular carcinoma. Clin Transplant. 2005 Apr;19(2):175-80.

38. Vennarecci G, Ettorre GM, Antonini M, Santoro R, Maritti M, Tacconi $G$, et al. First-line liver resection and salvage liver transplantation are increasing therapeutic strategies for patients with hepatocellular carcinoma and child a cirrhosis. Transplant Proc. 2007 Jul-Aug;39(6): 1857-60.

39. Del Gaudio M; Cescon M; Ercolani G; Balduzzi A; Pellegrini S; Ravaioli M; Cuccheti A; Bertuzzo VR; Zanfi C; Morelli MC; Pinna AD. (2014). Long-term outcome of salvage liver transplantation for HCC recurrence after liver resection: University of Bologna experience. Liver Transplantation, 20, S132-S133. Retrieved from http://www.embase. $\mathrm{com} / \mathrm{search} /$ results? subaction=viewrecord\&from $=$ export\&id=L71562 256\%5Cnhttp://dx.doi.org/10.1002/lt.23901\%5Cnhttp://sfx.aub.aau.d k/sfxaub?sid=EMBASE\&issn=15276465\&id=doi:10.1002\%2Flt.23901 \&atitle=Long-term+outcome+of + salvage+liver+transplantation

40. Poon RT, Fan ST, Lo CM, Liu CL, Wong J. Long-term survival and pattern of recurrence after resection of small hepatocellular carcinoma in patients with preserved liver function: implications for a strategy of salvage transplantation. Ann Surg. 2002 Mar;235(3):373-82.

41. Majno PE, Sarasin FP, Mentha G, Hadengue A. Primary liver resection and salvage transplantation or primary liver transplantation in patients with single, small hepatocellular carcinoma and preserved liver function: an outcome-oriented decision analysis. Hepatology. 2000
Apr;31(4):899-906.

42. Liang BY, Huang ZY, Zhou SJ, Hou P, Wang SF, Jiang B, et al. Primary results of salvage liver transplantation in the patients with un-resectable recurrent hepatocellular carcinoma after initial liver resection. Hepatogastroenterology. 2014 0ct;61(135):2014-20.

43. Lai Q, Avolio AW, Lerut J, Singh G, Chan SC, Berloco PB, et al. Recurrence of hepatocellular cancer after liver transplantation: the role of primary resection and salvage transplantation in East and West. J Hepatol. 2012 Nov;57(5):974-9.

44. Guerrini GP, Gerunda GE, Montalti R, Ballarin R, Cautero N, De Ruvo $\mathrm{N}$, et al. Results of salvage liver transplantation. Liver Int. 2014 Jul;34(6):e96-e104.

45. Hu Z, Zhou J, Xu X, Li Z, Zhou L, Wu J, et al. Salvage liver transplantation is a reasonable option for selected patients who have recurrent hepatocellular carcinoma after liver resection. PLoS One. 2012; 7(5):e36587.

46. Hwang S, Lee SG, Moon DB, Ahn CS, Kim KH, Lee YJ, et al. Salvage living donor liver transplantation after prior liver resection for hepatocellular carcinoma. Liver Transpl. 2007;13(5):741-6. http://doi.org/ 10.1002/tt.21157

47. Kitajima T, Fujimoto $\mathrm{Y}$, Hatano E, Nishida $\mathrm{H}$, Ogawa K, Mori A, et al. Salvage living-donor liver transplantation for liver failure following definitive radiation therapy for recurrent hepatocellular carcinoma: a case report. Transplant Proc. 2015 Apr;47(3):804-8.

48. Bhangui P, Allard MA, Vibert E, Cherqui D, Pelletier G, Cunha AS, et al. Salvage Versus Primary Liver Transplantation for Early Hepatocellular Carcinoma: Do Both Strategies Yield Similar Outcomes? Ann Surg. 2016 Jul;264(1):155-63.

49. Ng KK, Lo CM, Liu CL, Poon RT, Chan SC, Fan ST. Survival analysis of patients with transplantable recurrent hepatocellular carcinoma: implications for salvage liver transplant. Arch Surg. 2008 Jan;143(1):68-74; discussion 74.

50. Lee HS, Choi GH, Joo DJ, Kim MS, Choi JS, Kim SI. The clinical behavior of transplantable recurrent hepatocellular carcinoma after curative resection: implications for salvage liver transplantation. Ann Surg Oncol. 2014 Aug;21(8):2717-24.

51. Lee S, Hyuck David Kwon C, Man Kim J, Joh JW, Woon Paik S, Kim BW, et al. Time of hepatocellular carcinoma recurrence after liver resection and alpha-fetoprotein Are important prognostic factors for salvage liver transplantation. Liver Transpl. 2014 Sep;20(9): 1057-63.

52. Qu W, Zhu ZJ, Sun LY, Wei L, Liu Y, Zeng ZG. Salvage liver transplantation for hepatocellular carcinoma recurrence after primary liver resection. Clin Res Hepatol Gastroenterol. 2015 Feb;39(1):93-7. 